\title{
$\mathrm{SiC}(\mathrm{w}) / \mathrm{Si}_{3} \mathrm{~N}_{4}$ の強度及び䩲性に及ぼすウイスカ一表面被覆と配向の効果
}

\author{
松井辰珠・小村 修·三宅雅也 \\ 住友電気工業 (株), 664 兵庫県伊丹市昆陽北 1-1-1
}

\section{The Effects of Surface Coating and Orienting of Whiskers on Mechanical Properties of $\mathrm{SiC}(\mathrm{w}) / \mathrm{Si}_{3} \mathrm{~N}_{4}$}

\author{
Tatsuji MATSUI, Osamu KOMURA and Masaya MIYAKE
}

Sumitomo Electric Industries, Ltd., 1-1-1, Koya-kita, Itami-shi, Hyogo 664

[Received April 12, 1991; Accepted July 18, 1991]

In order to strengthen and toughen $\mathrm{Si}_{3} \mathrm{~N}_{4}$ ceramics by addition of SiC-whiskers, we tried the control of interfacial properties between whisker and matrix and of orientation of whiskers. For interfacial control, the effects of $\mathrm{Al}_{2} \mathrm{O}_{3}, \mathrm{ZrO}_{2}$ and carbon coating to the surface of whiskers were studied. The flexural strength and the fracture toughness of $\mathrm{Si}_{3} \mathrm{~N}_{4}$ composite containing $\mathrm{Al}_{2} \mathrm{O}_{3}$-coated whiskers by decomposition of aluminum stearate, were stronger (1107 MPa) and larger (10.2 $\left.\mathrm{MPa} \cdot \mathrm{m}^{1 / 2}\right)$ than those of the composite with noncoated whiskers. TEM observation revealed that $\mathrm{Al}_{2} \mathrm{O}_{3}$-coated whiskers in the composite had smoother surface than non-coated whiskers and that a film-layer was formed at the interface between whisker and matrix. For orientation control, the flexural strength and the creep rupture resistance at $1250^{\circ} \mathrm{C}$ of $\mathrm{Si}_{3} \mathrm{~N}_{4}$ composite, reinforced with uni-directionally oriented whiskers by the doctor-blade method, were much stronger (1180 MPa) and much larger than those of monolithic $\mathrm{Si}_{3} \mathrm{~N}_{4}$ ceramics. After creep testing, the new stacking fault and dislocation in the whiskers were observed by TEM. On the basis of these results, the mechanisms of toughening and high-temperature strengthening of $\mathrm{SiC}(\mathrm{w}) / \mathrm{Si}_{3}$ $\mathrm{N}_{4}$ have been discussed.

Key-words : Silicon nitride, SiC whisker, Coating, Interfacial bonding, Uni-directional orientation, Fracture toughness, High-temperature strength

\section{1. 緒言}

$\mathrm{Si}_{3} \mathrm{~N}_{4}$ セラミックスは耐摩耗性, 耐食性, 耐熱衝撃性に 優れ，更に強度・勒性ともにバランスのとれた材料であり 自動車部品や機械部品等の構造材料として期待されてい る. しかしながらその破壊靶性や高温強度は実用材料とし てはいまだ十分とはいえないためウイスカーや長繊維を複 合して高強度, 高勒性化を図万うとする研究が活発に行わ れている.

ウイスカー強化型セラミックスにおける複合効果とし て, クラックディフレクション1), 図 1 に示すようなウイ スカーの引き抜き（プルアウト）党文はイスカー/マトリ ックス界面の剝離（デボンド）光に起因する橋かけ（ブリ ッジング）による高䩲性化 ${ }^{4)}$ ，また，応力下での粒界のす べりを抑制することによる高温高強度化 ${ }^{5}$ が期待できる.

これらの効果の発現のために特に必要な条件は, (1)ウイス カーとマトリックスとの間の界面結合力が適度に抑制され ていること，(2)亀裂の進展面に対して垂直な方向にできる だけ多くのウイスカーが配向・分散していること, (3)ウイ スカーの強度が焼結後も保持されていること, であるとい われている6),7). 界面結合力については, $\mathrm{SiC}$ 繊維強化 $\mathrm{Si}_{3}$ $\mathrm{N}_{4}$ に抢ける繊維/マトリックス界面のせん断強度の測定 ${ }^{8)}$ や， $\mathrm{SiC}$ ウイスカー強化 $\mathrm{Si}_{3} \mathrm{~N}_{4}$ に抢いてウイスカー界面に
1.Interface Control

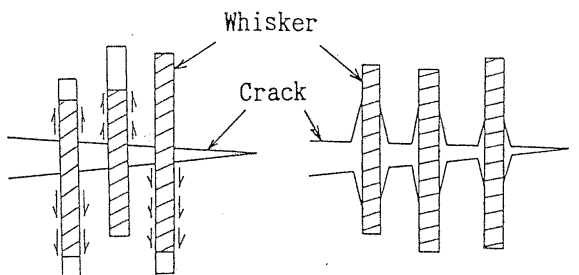

$\langle$ Pull-out bridging $\rangle$

$\langle$ Debond bridging
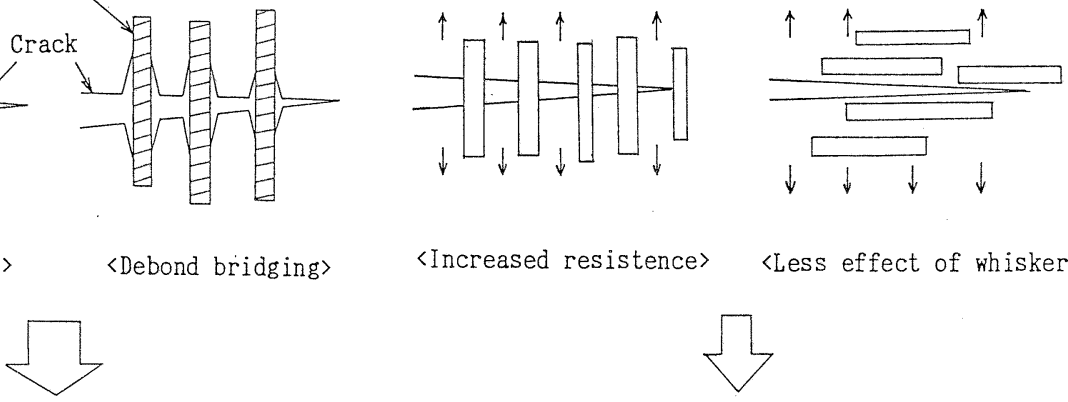

Modification of bonding strength of interface

〈Increased resistence〉 〈Less effect of whiskers〉

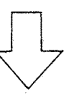

Uni-directional orientation of whiskers

Fig. 1. Schematic illustration of control factor for toughening machanism by whiskers. 
$\mathrm{Y}_{2} \mathrm{O}_{3}-\mathrm{SiO}_{2}, \mathrm{C}, \mathrm{BN}$ を修飾し破壊靶性に及ぼす効果を検討 した報告9)がある。また，ウイスカ一の配向効果について は，押し出し成形や射出成形により一軸配向させることに より靶性が向上している(10),11)。

しかしながら，ウイスカ一強化材ではウイスカー/マト リックス界面の結合強度について検討した報告例はまだ少 なく，またそれを直接測定するのも困難であり，どのよう な界面介在層むるいは反応層が強度・鞋性向上に最も有効 であるかはいまだ明確な知見が得られていないのが現状で ある，东た，ウイスカーの配向効果についても破壊靰性以 外の機械的特性について更に検討が必要である。

そこで本報告では， $\mathrm{SiC}$ ウイスカー強化 $\mathrm{Si}_{3} \mathrm{~N}_{4}$ セラミッ クス $\left(\mathrm{SiC}(\mathrm{w}) / \mathrm{Si}_{3} \mathrm{~N}_{4}\right)$ に抢けるウイスカー/マトリックス の界面結合力と強度・靶性との関係を明らかにすることを 目的として, ウイスカ一表面の被覆材が強度・靶性等に及 ぼす効果を調べた。 また，ウイスカーを一軸配向させて添 加する効果及び配向性の違いによる効果について，破壤䩚 性，高温強度及び高温クリープ特性を中心に検討を行い， それらの結果をもとにウイスカー複合による高勒性化及び 高温高強度化の機構について考察した。

\section{2. 実験方法}

\section{$2.1 \mathrm{SiC}$ ウイスカー表面の被覆方法ならびに焼結体の 作製}

$\mathrm{SiC}$ ウイスカーと $\mathrm{Si}_{3} \mathrm{~N}_{4}$ マトリックスの界面結合力を变 化させるためのウイスカ一表面の被覆材として, $\mathrm{Al}_{2} \mathrm{O}_{3}$, $\mathrm{ZrO}_{2}$ そしてCを選んだ. $\mathrm{SiC}$ ウスカーと $\mathrm{Si}_{3} \mathrm{~N}_{4}$ 粒子界 面は焼結温度（ $\left.1700^{\circ} \mathrm{C}\right)$ 以下では反応しない10),12)のに 対し， $\mathrm{Al}_{2} \mathrm{O}_{3}$ は界面反応を促進し， C は反応を阻害し，ま た $\mathrm{ZrO}_{2}$ はその中間的な役割を果たすものと予想された。 この反応性の違いによって界面結合力が変化し，ひいては 複合材の強度あるいは鞖性を変化させることがでさると考 えた.

ウイスカ一表面上に酸化物の前駆体を付着させその熱分 解により $\mathrm{Al}_{2} \mathrm{O}_{3}$ の均一な被覆層を形成させる方法を図 2 に示す. SiCウイスカー（東海カーボン製，TWS-100, 平均径約 $0.5 \mu \mathrm{m}$, 長さ $5 \sim 15 \mu \mathrm{m}, \beta$ 型） $100 \mathrm{~g}$ k対しス

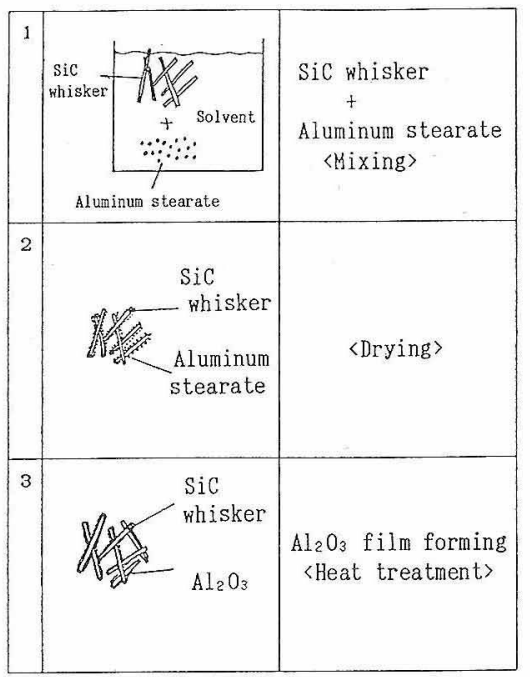

Fig. 2. Process of $\mathrm{Al}_{2} \mathrm{O}_{3}$ coating on $\mathrm{SiC}$ whisker surfaces.

テアリン酸アルミニウム（安田薬品製） $100 \mathrm{~g}$ をタノ一 ル中で混合し乾燥後，大気中 $900^{\circ} \mathrm{C} て ゙ 2$ 時間熱処理して $\mathrm{Al}_{2} \mathrm{O}_{3}$ （推定量約 $10 \mathrm{~g}$ ）に変換した. $\mathrm{ZrO}_{2}$ 被覆についても 硝酸ジコニル（高純度化学研究所，33 g) を用いて同様 に行った. ウイスカーに対する前駆体の混合量は，被覆す る酸化物の膜厚が $\mathrm{SiC}$ ウイスカー表面に均一に被覆され たと仮定してウイスカー直径の約 $1 / 50$ となるように決定 した．C被覆ウイスカーは市肘品を用いた。図 3 に被覆し ていないウイスカー並びに $\mathrm{Al}_{2} \mathrm{O}_{3}, \mathrm{ZrO}_{2} ， \mathrm{C}$ を被覆したウ イスカーの走査型電子顕微鏡 (SEM) 像を示す。 $\mathrm{Al}_{2} \mathrm{O}_{3}$ 及び $\mathrm{ZrO}_{2}$ はウイスカ一表面上に粒状に均一分布しており， $\mathrm{X}$ 線回折結果より結晶型は $\mathrm{Al}_{2} \mathrm{O}_{3}$ が $\alpha$ 型, $\mathrm{ZrO}_{2}$ が単斜晶 であった。C被覆ウイスカー（東海カーボン製，TWS100 にC を表面処理したもの，膜厚 $5 \mathrm{~nm}$ ）の表面はなめ らかでX 線的には結晶ではなくアモルファスであると考 えられた。

焼結体の作製は図 4 に示すように，被覆ウイスカー20 $\mathrm{wt} \%$ と，焼結助剂として $\mathrm{Y}_{2} \mathrm{O}_{3}$ (信越化学工業製，SU） を $8 \mathrm{wt} \%$ 及び $\mathrm{Al}_{2} \mathrm{O}_{3}$ （住友化学工業製，AKP50）を 2 $\mathrm{wt} \%, \mathrm{Si}_{3} \mathrm{~N}_{4}$ 粉末（宇部興産製，E10） $70 \mathrm{wt} \%$ をタ）
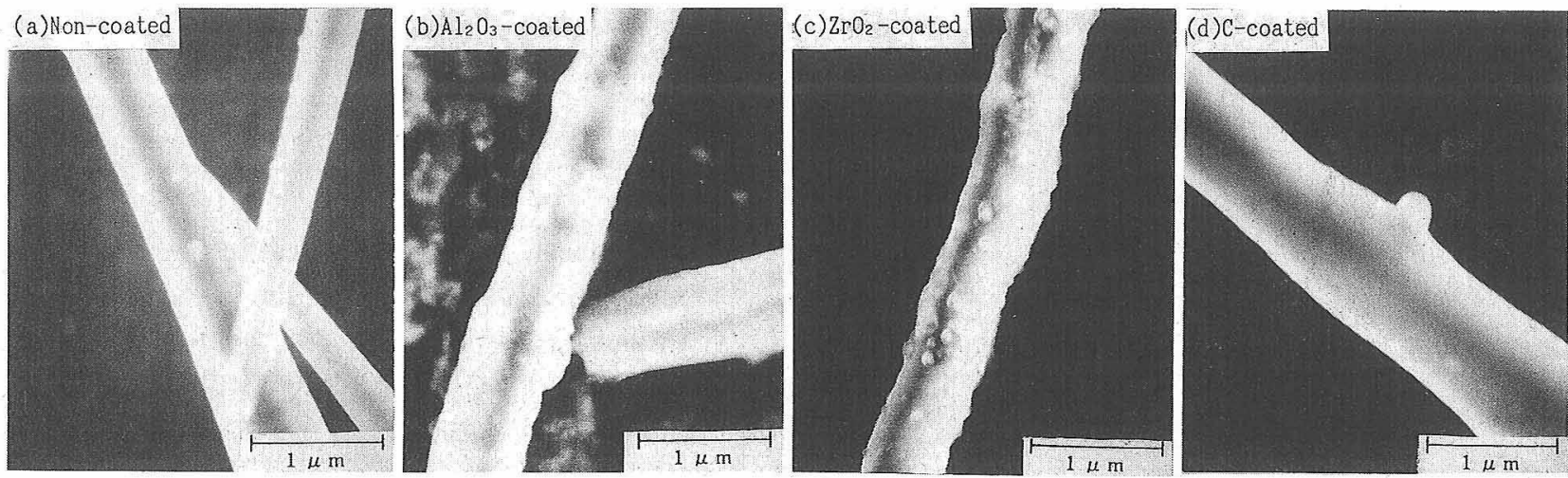

Fig. 3. $\mathrm{SEM}$ photographs of non-coated $\mathrm{SiC}$ whisker (a), $\mathrm{Al}_{2} \mathrm{O}_{3}$-coated (b), $\mathrm{ZrO}_{2}$-coated (c) and C-coated (d) whisker. 


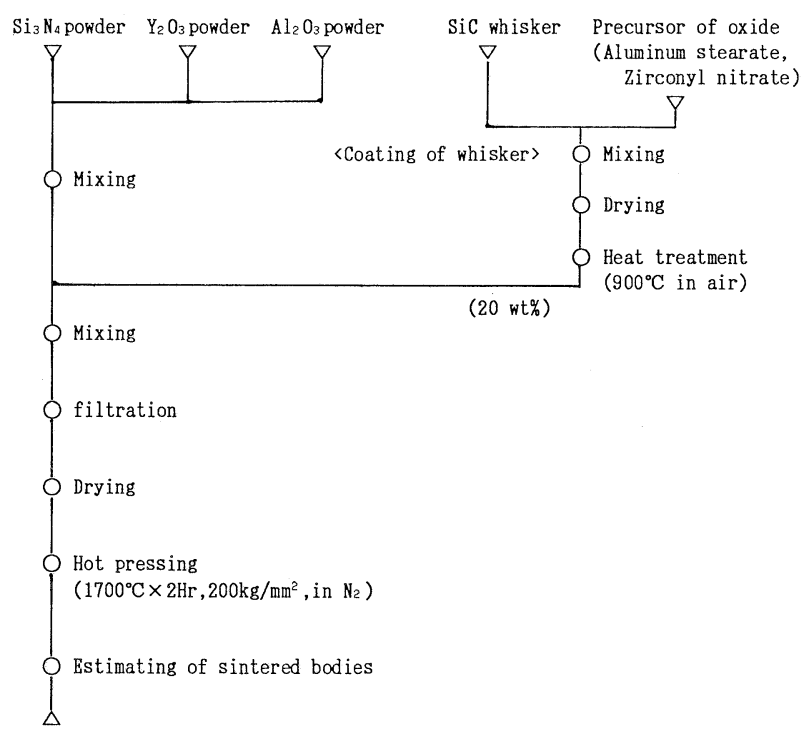

Fig. 4. Fabricating process of $\mathrm{SiC}(\mathrm{w}) / \mathrm{Si}_{3} \mathrm{~N}_{4}$ composites.

一ル中で混合し，吸引洰過によりシート状に成形し，乾燥 後積層してホットプレス法により焼結した. 得られた焼結 体より $3 \times 4 \times 36 \mathrm{~mm}$ サイズの試験片を切り出し, アルキ メデス法により密度を測定した。強度（室温及び $1250^{\circ} \mathrm{C}$ ) はスパン $30 \mathrm{~mm}$ の 3 点曲げ試験により求めた。破壊靱性 値は, 上記試験片のホットプレスの加圧軸方向に対し垂直 な面に刃幅 $0.1 \mathrm{~mm}$ のダイヤモンドホイールで深さ 0.75 $\mathrm{mm}$ のスリットを導入し SENB 法により求めた。 また, 焼結体中の残留応力を $\mathrm{X}$ 線応力測定法により測定した. 回折面は $\mathrm{Si}_{3} \mathrm{~N}_{4}$ の (323) 面, 特性 $\mathrm{X}$ 線は $\mathrm{Cu} \mathrm{K} \alpha$ を用い $\psi$ 一定法により測定し, 応力値算出の際の $\mathrm{X}$ 線応力測定定 数は $-733 \mathrm{MPa} / \operatorname{deg}$ の值を用いた. ウイスカーとマトリ ックスの間の界面の様子は透過型電子顕微鏡（TEM）で 観察した.

\section{$2.2 \mathrm{SiC}$ ウイスカーの配向方法}

モノリシック材に対するウイスカーの複合効果をより顕 著に発揮させるためのウイスカーの添加方法として, ドク ターブレード法による一軸配向添加の検討を行い, 得られ た複合材とモノリシック材との特性の比較によりその添加 効果を, また配向方向の異なる試片についての比較により その配向効果を調べた. 図 5 にドクターブレードシートの 作製方法を示す. 2.1 節と同様にウイスカー（被覆なし） $20 \mathrm{wt} \%, \mathrm{Si}_{3} \mathrm{~N}_{4} 70 \mathrm{wt} \%$, 助剂 $10 \mathrm{wt} \%$ と, 更に有機バイ ンダーをエタノール中で十分に混合し, 脱泡・粘度調節 後, 厚さ $0.3 \mathrm{~mm}$ のグリーンシートとした.このシートを $100 \times 100 \mathrm{~mm}$ の大きさに切り出し, ウイスカーの配向方 向を揃えて積層し, 図 4 と同じ条件でホットプレスした。 得られた焼結体から $3 \times 4 \times 36 \mathrm{~mm}$ サイズの試験片を, 図 6 のようにホットプレス加圧方向とドクターブレード引き 出し方向に応じて 4 種類切り出し, 各試験片について, 3 点曲げ強度（室温及び $1250^{\circ} \mathrm{C}$ ), 破壊靶性值を測定し, ク ラック進展の様子をSEM で観察した．またクリープ試験 を, $343 \mathrm{MPa}$ の 3 点曲げ応力下, 大気中 $1250^{\circ} \mathrm{C}$ で行い,

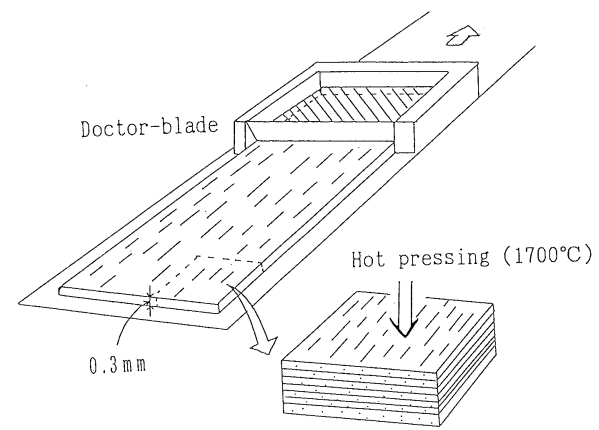

Fig. 5. Illustration of doctor-blade method.

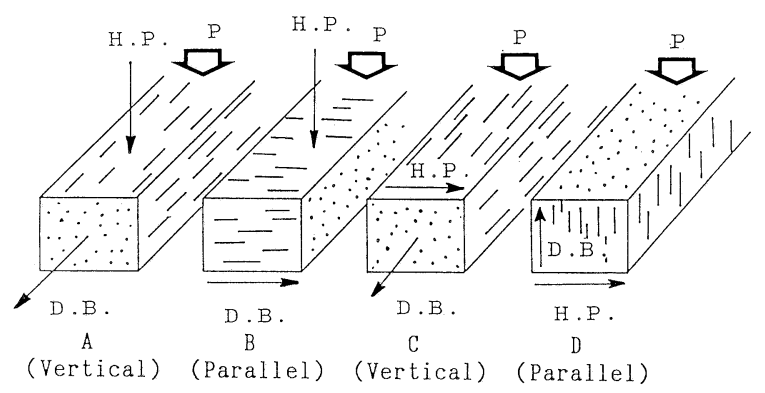

Fig. 6. Specimen for bending experiments classified according to the direction of power on 3-point bending $(\mathrm{P})$, hot pressing (H.P.) and drawing of slurry by doctor-blade method (D.B.).

クリープ破断後の試験片中の引張応力がかかっていた部分 の微構造を TEM で観察した.

\section{3. 実験結果}

\subsection{SiC ウイスカー表面被覆効果の検討}

\subsection{1 被覆ウイスカー複合材の機械的特性}

被覆处理をしていないウイスカー及び $\mathrm{Al}_{2} \mathrm{O}_{3}, \mathrm{ZrO}_{2}, \mathrm{C}$ をそれぞれ被覆したウイスカーを複合した各複合材のホッ トプレス後の相対密度は，いずれも $99 \%$ 以上に達してお り緻密な焼結体であった。図 7 に各複合材の室温及び $1250^{\circ} \mathrm{C}$ での曲げ強度（ $\sigma_{\mathrm{RT}}$ 及び $\left.\sigma_{1250^{\circ} \mathrm{C}}\right)$ そして破壊勒性值 $\left(K_{\mathrm{IC}}\right)$ の比較結果を示す.

$\sigma_{\mathrm{RT}}$ は，被覆なしウイスカー複合材（以下被覆なし材） が平均 $990 \mathrm{MPa}$ であったのに対し $\mathrm{Al}_{2} \mathrm{O}_{3}$ 被覆ウイスカー 複合材（以下 $\mathrm{Al}_{2} \mathrm{O}_{3}$ 被覆材）は平均 $1107 \mathrm{MPa}$ とより高強 度となった。また $\mathrm{C}$ 被覆ウイスカー複合材（以下 $\mathrm{C}$ 被覆 材）でも $1054 \mathrm{MPa}$ と強度が向上したが， $\mathrm{ZrO}_{2}$ 被覆ウイ スカ一複合材（以下 $\mathrm{ZrO}_{2}$ 被覆材）は864 MPa と逆に低下 した.

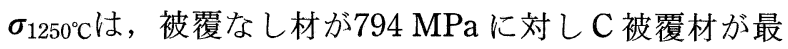
も高く平均 $921 \mathrm{MPa}$ となり室温強度と比較しての強度低 下も小さかった. $\mathrm{Al}_{2} \mathrm{O}_{3}$ 及び $\mathrm{ZrO}_{2}$ 被覆材はともに, 被覆 なし材に比べて高温強度が低い結果となった.

$K_{\mathrm{IC}}$ は，被覆なし材が $8.7 \mathrm{MPa} \cdot \mathrm{m}^{1 / 2}$ であったのに対し て $\mathrm{Al}_{2} \mathrm{O}_{3}$ 被覆材では $10.2 \mathrm{MPa} \cdot \mathrm{m}^{1 / 2}$ と著しい靯性の向上 がみられた。一方 $\mathrm{ZrO}_{2}$ 被覆材では $K_{\mathrm{IC}}$ は $7.4 \mathrm{MPa} \cdot \mathrm{m}^{1 / 2}$, 


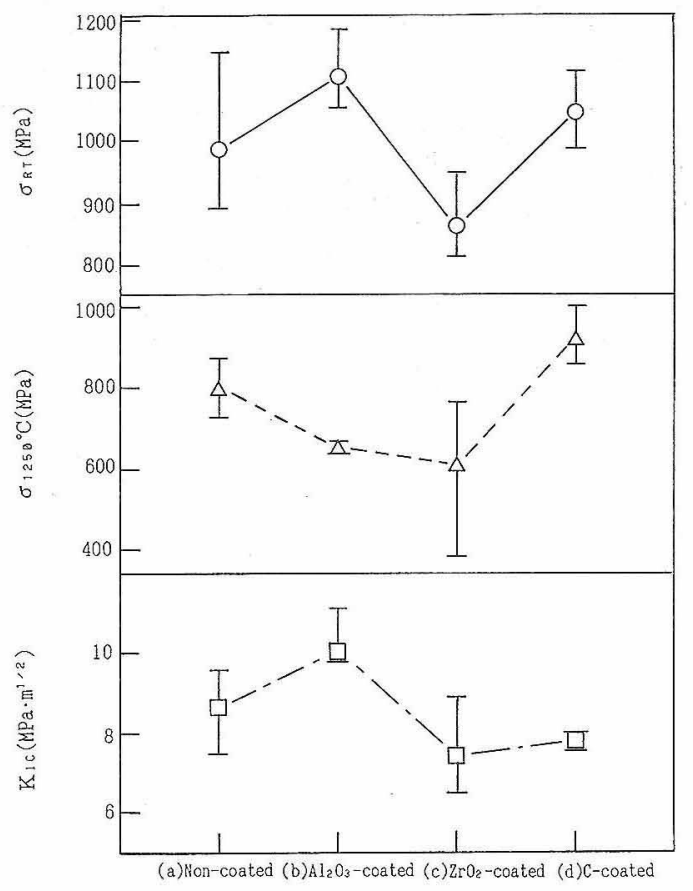

Fig. 7. Mechanical properties of composites containing whiskers (a) non-coated, (b) $\mathrm{Al}_{2} \mathrm{O}_{3}$-coated, (c) $\mathrm{ZrO}_{2}$-coated and (d) C-coated.

$\mathrm{C}$ 被覆材では7.8 $\mathrm{MPa} \cdot \mathrm{m}^{1 / 2}$ であり，いずれも被覆なし材 に比べて靱性值は低下した.

すなわち， $\mathrm{Al}_{2} \mathrm{O}_{3}$ 被覆材では室温強度，靱性共に向上す るが高温での強度の低下がみられ，また C 被覆材では靱 性は低下するが高温強度が著しく向上し， $\mathrm{ZrO}_{2}$ 被覆材で は室温，高温強度及び鞋性のいずれも低下することが分か った。この結果から，ウイスカーとマトリックスの界面に おいて反応すると思われる $\mathrm{Al}_{2} \mathrm{O}_{3}$ 被覆が複合材の破壊鞋 性を向上させる効果が岁り，反応が進むないと思われる $\mathrm{C}$ 及び $\mathrm{ZrO}_{2}$ 被覆は逆に靶性を低下させる傾向を示すと考 えることができる。そこでこの $\mathrm{Al}_{2} \mathrm{O}_{3}$ 被覆による高靶化 効果について更に検討するため複合材中を進むクラックの 進展挙動，更には複合材中のウイスカー/マトリックス界 面の状態を観察した。

\section{1 .2 複合材中のクラック進展挙動}

$\mathrm{Al}_{2} \mathrm{O}_{3}$ 被覆材及び $\mathrm{C}$ 被覆材の焼結体表面にそれぞれビッ
カース圧子を押し込み, 発生したクラックの進展挙動を SEM により観察した. 図8のように，C被覆材ではウイ スカー/マトリックス界面が剝離しそれに沿ってクラック がディフレクションしている個所が随所にみられた（図 8( ii )). $\mathrm{Al}_{2} \mathrm{O}_{3}$ 被覆材ではそのようなディフレクションは あまりみられず，むしろウイスカーの橋かけ現象が多く観 察された（図 8(i ))。

\subsection{3 ウイスカー/マトリックス界面観察}

$\mathrm{Al}_{2} \mathrm{O}_{3}$ 被覆の効果についてウイスカー/マトリックス界 面に注目し，被覆なしの場合及び亀裂進展挙動が明らかに 違うC被覆の場合と比較しながら TEM 観察を行った。 図 9 (a) に被覆なし材，（b) K $\mathrm{Al}_{2} \mathrm{O}_{3}$ 被覆材そして(c)にC 被覆材に抢ける界面の状態を示す。被覆なし材と $\mathrm{C}$ 被覆 材の場合は界面には介在層は2られず界面反応は起こって いないと考えられる（図中 $\rightarrow$ 印）。一方， $\mathrm{Al}_{2} \mathrm{O}_{3}$ 被覆材で は，界面に $\mathrm{Al}_{2} \mathrm{O}_{3}$ 被覆に由来すると思われる膜状の介在 層が観察された（図中ょ印）。この層は観察時に試料の傾 きを変えても同様にみられ界面の重複によるものではない と考えられた。また，被覆なし材ではウイスカーの表面は 凹円が激しく，マトリックス粒子によって大きなひずみを 受けているのが分かるが， $\mathrm{Al}_{2} \mathrm{O}_{3}$ 被覆材では，ウイスカ一 表面は非常になめらかであり凹凸が少ない。これは $\mathrm{Al}_{2} \mathrm{O}_{3}$ 被膜により，ホットプレス焼結時に界面の濡れ性が改善さ れ，ウイスカーにかかる歪や損傷が低減されたことによる と推定される。
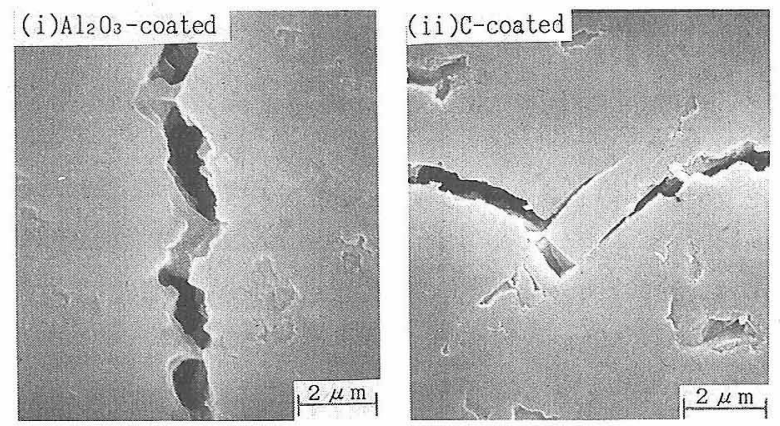

Fig. 8. Crack propagation in (i) $\mathrm{Al}_{2} \mathrm{O}_{3}$-coated and (ii) C-coated whisker containing composites.
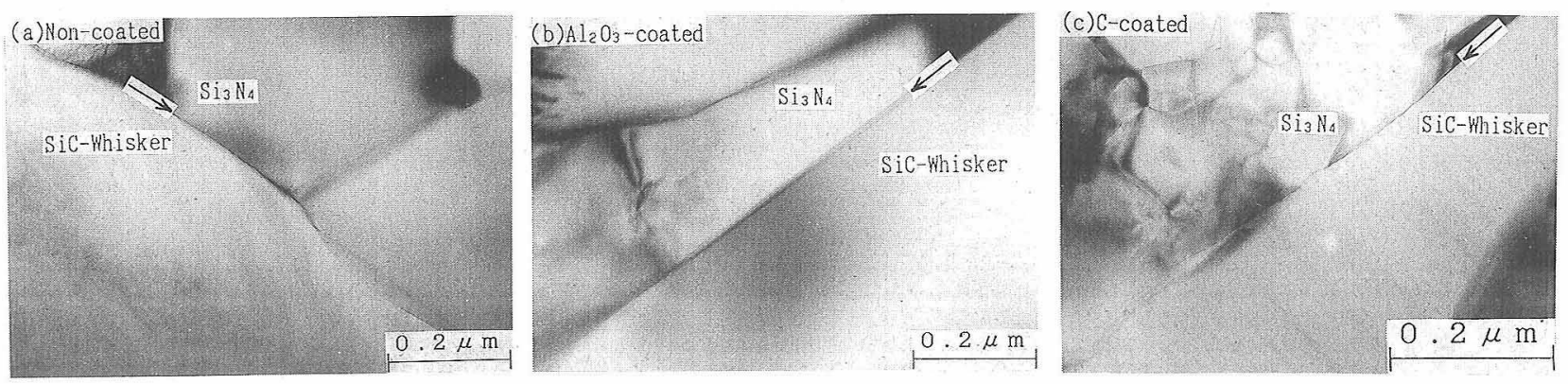

Fig. 9. TEM photographs of whisker-matrix interface of (a) non-coated, (b) $\mathrm{Al}_{2} \mathrm{O}_{3}$-coated and (c) C-coated whisker containing composites. The arrows show the interface. 


\section{$3.2 \mathrm{SiC}$ ウイスカーの配向効果の検討}

\subsection{1 ウイスカーの一軸配向添加及び配向性の䔔いに よる効果}

ドクターブレード法を用いて作製したグリーンシート中 に存在するウイスカーは図10のようにほぼ一方向に配向し ていた．これらのシートを積層してホットプレスした焼結 体から図 6 のように切り出した 4 種類の試片（A，B，C, D）について評価を行った。焼結体の試片 A 陚片 Cで はクラック進展面に対してウイスカーは垂直に配向してお り（以下垂直配向材 $\mathrm{A}$ 及び C), 試片 B では進展面に平行 かつ進展方向に垂直（以下平行配向材 $\mathrm{B}$ ), 試片 D では進 展面に平行加進展方向に平行に配向している（以下平行

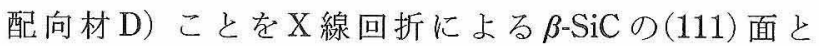
(220)面のピーク強度比の差より確認した. 図11に各試片

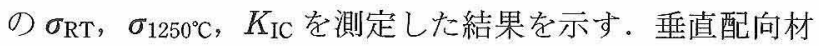
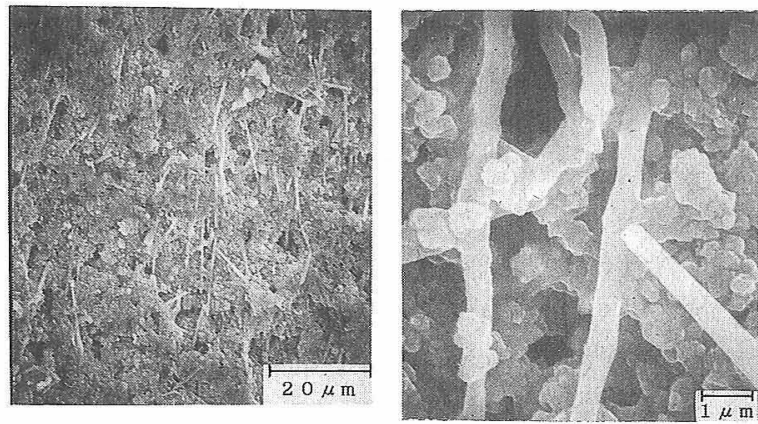

Fig. 10. Orientation of whiskers in doctor-blade sheets.

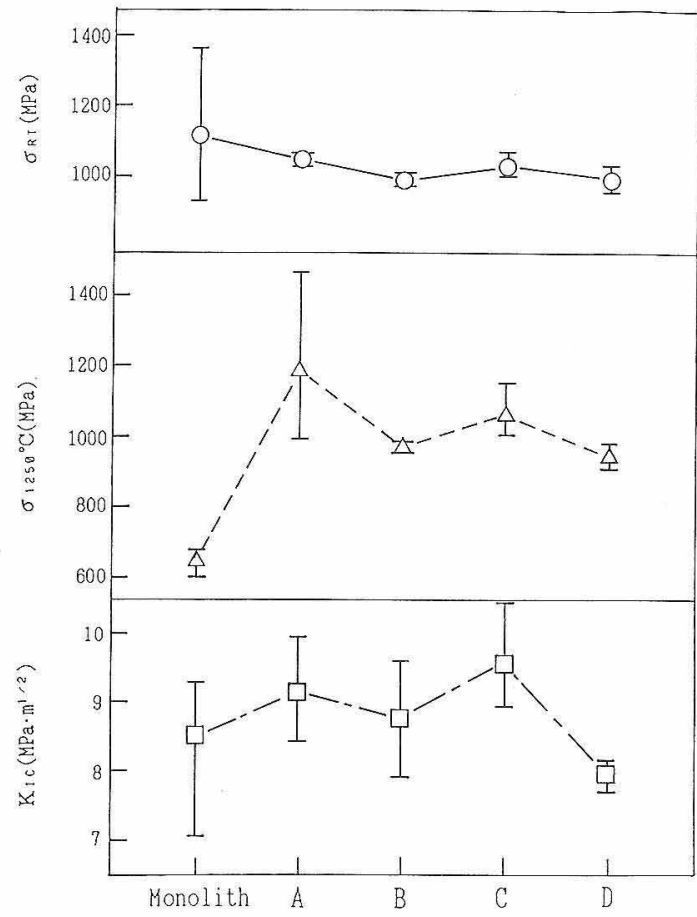

Fig. 11. Mechanical properties of monolith, specimen A (vertical), B (parallel), C (vertical) and D (parallel) classified according to whisker orientation as shown in Fig. 6.

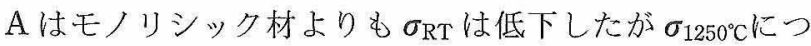
いては646 MPa から $1180 \mathrm{MPa}$ と2 倍近く向上した。 た，垂直配向材 $\mathrm{A}$ は平行配向材 $\mathrm{D}$ に比べて $K_{\mathrm{IC}}$ が1.15

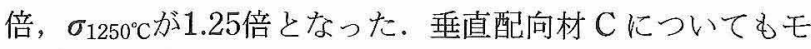
ノリシック材及び平行配向材に比較して A とほぼ同様の 傾向を示した，このことから，ウイスカーを配向させた複 合材は破壞靱性のみならずむしろ高温強度向上に顕著な効 果を発揮することが分かった。

そこで垂直配向による $K_{\mathrm{IC}}$ 向上効果についてクラック 進展挙動を観察し，高温強度向上効果について更にクリー プ試験を行い倹討した。

\subsection{2 クラック進展挙動}

試片Aのホットプレス面にビッカース圧子を押し込み， 各方向に発生したクラックの進展挙動を調べた。図12の （i ）はクラック進展方向に対してウイスカーが垂直配向， （ii）は平行配向している場合である. 平行配向ではクラッ クはウイスカーの配向方向に沿いながらほとんど直進して いるのに対し，垂直配向ではクラックディフレクションや ウイスカープルアウトが随所にみられ，この効果によって 垂直配向材の $K_{\mathrm{IC}}$ が向上したものと思われる.

\subsection{3 クリープ特性への影響}

図13はモ)リシック材及び複合材（垂直配向材 A と平 行配向材 D) のクリープ特性を示している。モモノリシッ

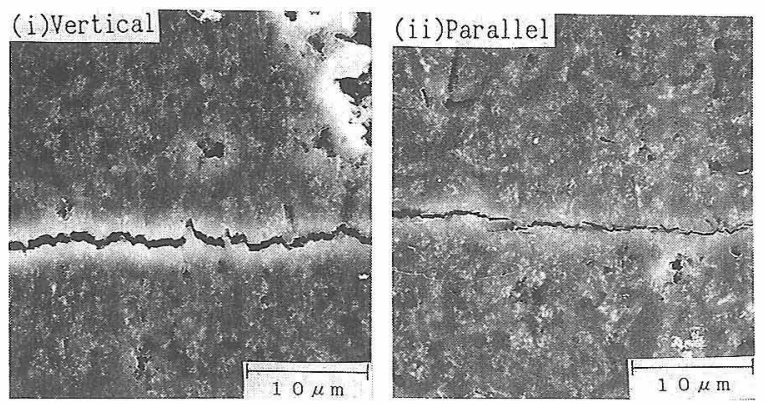

Fig. 12. Comparison of crack propagation configuration between (i) vertical and (ii) parallel orientation of whiskers.

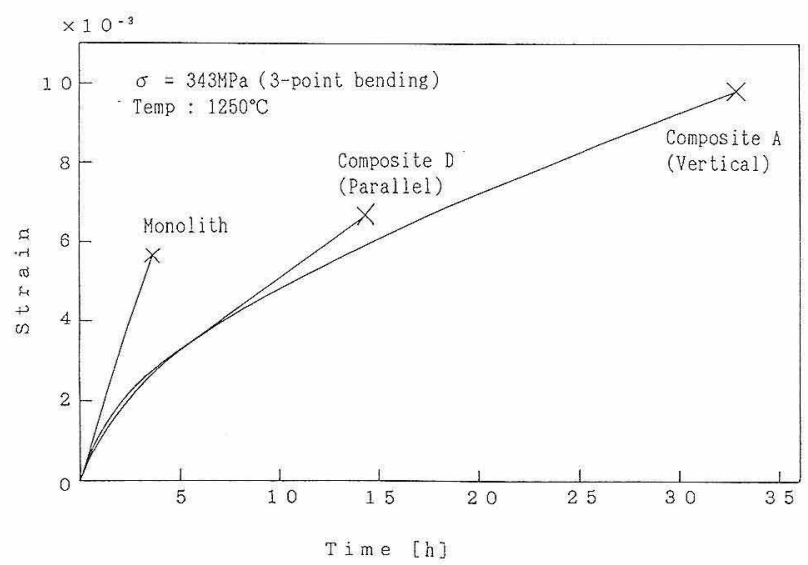

Fig. 13. Creep resistance properties of monolith, composites of specimens A (vertical) and D (parallel) shown in Fig. 6. 
ク材に比べて複合材の方が昰み速度が小さいことが分かっ た．また垂直配向材 A と平行配向材 D とを比較すると垂 直配向材 $\mathrm{A}$ の方が歪み量が多くなりその結果クリープ破 断時間が約 2 倍， またモノリシック材に対しては約 9 倍 となった。 すなわち, ウイスカー垂直配向材はモノリシッ ク材に比べて負荷応力に対する歪み速度が小さくかつ破断 までの歪み量が多いためクリープ破断時間が長くなったと いえる.

\section{4. 考 察}

\section{1 破壊䩗性に及ぼすウイスカー表面への $\mathrm{Al}_{2} \mathrm{O}_{3}$ 被覆 の効果}

ウイスカー表面に C を被覆すると亀裂進展の際に界面 剥離やディフレクションが起こりやすくなり， $\mathrm{Al}_{2} \mathrm{O}_{3}$ 被覆 材では逆に起こりにくくなったこと（図 8）は，C被覆と $\mathrm{Al}_{2} \mathrm{O}_{3}$ 被覆では界面の結合力に変化が生じていることを示 唆するものである. 芦塚ら ${ }^{13)}$ は C 被覆 $\mathrm{SiC}$ ウイスカー/コ ーディエライトに拈いて C 被覆により界面結合力が弱め られ剝離が起こると指摘しており，これは本結果と傾向を 同じくするものである. $\mathrm{Al}_{2} \mathrm{O}_{3}$ 被覆材中のウイスカーとマ トリックス間の界面介在層（図 9）は，ウイスカー表面に 被覆された状態の $\mathrm{Al}_{2} \mathrm{O}_{3}$ の層（図 3）とは異なり均一な膜 状に変化していることから, 焼結中に界面に拈いて何らか の反応が起こったと推察できる．更に $\mathrm{Al}_{2} \mathrm{O}_{3}$ 被覆材では 亀裂進展の際，主にウイスカーのブリッジングがみられ た。このようなブリッジングによる高靱化のメカニズムに ついては, Kelly ${ }^{2}$ が, 橋かけの際に起こるウイスカーの 引き抜けの摩擦力によりエネルギーが解放されるプルアウ トブリッジングを, Becher ら³)が，プルアウトに比べて 界面結合力が強い場合に界面の剝離によって橋かけが起こ るデボンドブリッジングをそれぞれ提唱している（図 1). $\mathrm{Al}_{2} \mathrm{O}_{3}$ 被覆材がプルアウトかデボンドかは明らかでは ないが，少なくとも界面反応による結合力の適度な強化と ブリッジング機構とは対応していると考えられる．更に，

表 1 に示すように，複合材中に残留した応力を調べた結 果, $\mathrm{Al}_{2} \mathrm{O}_{3}$ を被覆すると複合材中の $\mathrm{Si}_{3} \mathrm{~N}_{4}$ にかかる圧縮残 留応力值が約 5 分の 1 に減少していることが分かった. このことは，焼結体内部の圧縮に対する引張りの応力バラ ンスを考慮するとウイスカーにかかる引張り残留応力が 5 分の 1 になったと言い換えることができ，ウイスカーに かかる引張り応力が緩和されることによりウイスカーの強 度が見掛け上向上したことになる．またウイスカー表面に

Table 1. Comparison of properties of non-coated and $\mathrm{Al}_{2} \mathrm{O}_{3}$-coated SiC-whisker containing $\mathrm{Si}_{3} \mathrm{~N}_{4}$.

\begin{tabular}{|c|c|c|c|c|}
\hline & $\begin{array}{c}R_{i c} \\
\left(\operatorname{Han}^{1 / 2}\right)\end{array}$ & $\begin{array}{l}\text { Residual stress of } \\
S i_{3} \|_{4}\left(k_{0} / \mathrm{m}^{2}\right)\end{array}$ & $\begin{array}{l}\text { Surface condition } \\
\text { of whiskers }\end{array}$ & Layer at interface \\
\hline non-coated & 8.7 & 10.7 & 吅出 & No \\
\hline $\mathrm{Al}_{2} \mathrm{O}_{3}$ coated & 10.2 & 2.1 & Smooth & Yes \\
\hline
\end{tabular}

かかる歪による凹凸も減少する事実から，劣化・損傷が低 減され，焼結前のウイスカーの強度特性が保持された複合 体となっていると推定される，以上より，靱性向上に対す るウイスカー表面被覆材としての $\mathrm{Al}_{2} \mathrm{O}_{3}$ の機能は次の 2 点が考えられる.

(1)界面反応制御一一界面反応層を形成し界面結合力を適 度に強める。

(2)ウイスカ一強度保持一一焼結中に界面に生じる歪や応 力を緩和する.

(1)については，界面が強固に反応しすぎるとクラックは ウイスカーを切って直進するのみでウイスカーの複合効果 は生かされないと考えられる。梳本実験における C被 覆材にみられたように界面剥離やディフレクションが顕著 に起こったからといって必ずしも破壊鞋性が向上するとは いえない。本研究の $\mathrm{Al}_{2} \mathrm{O}_{3}$ 被覆材ではクラック進展の際 ウイスカーがブリッジングを起こすことにより靶性が向上 したと考えられる.

(2)については，ウイスカー表面に被覆された $\mathrm{Al}_{2} \mathrm{O}_{3}$ は 焼結中に同じ表面上にある $\mathrm{SiO}_{2}$ と液相を形成することに より界面の濡れ性が改善されて, 焼結中の収縮により生じ る歪や熱膨張係数の差及びそれにより生じる残留応力を緩 和すると推察される.

\section{2 高温特性に及ぼすウイスカーの配向添加の効果}

ウイスカーをクラック進展面に垂直配向させて添加（垂 直配向材）するとウイスカーを添加しない場合（モノリシ

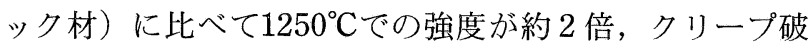
断時間が約 9 倍となった。また，クリープの際にモノリ シック材に比べて垂直配向材は歪み速度が約 8 分の 1 , 破 断までの歪み量が約1.7倍となった。更に同じ複合材でも 垂直配向材は平行配向材（クラック進展面に対して平行配 向させたもの）よりも歪み量が約1.5倍増加した.これら の結果からいえることは，ウイスカーが複合されることに より高温応力下での歪みに対する抵抗が増加するというこ とである．言い換えると高温での粒界ガラス相の軟化に伴 う $\mathrm{Si}_{3} \mathrm{~N}_{4}$ マトリックスの粒界すべりがウイスカーによるピ ン止め効果によってて起こりにくくなるといえる. 更に，ウ イスカーの配向をクラック進展面に垂直に揃えると複合材 の高温応力下での歪み量が増加するということである．こ れはウイスカーが配向して $\mathrm{Si}_{3} \mathrm{~N}_{4}$ マトリックスに橋をかけ たように存在するため, $\mathrm{Si}_{3} \mathrm{~N}_{4}$ の粒界すべりによって歪み 量が大きくなってもこのウイスカーによる歪み方向に対す る架橋効果により構造が保持され破断に至り難くなるため であると考えられる．以上より，配向添加されたウイスカ 一はマトリックスの粒界変形が起きても破断抵抗を増加さ せる. その結果，高温応力下においてはウイスカー自身に かなりの応力が負荷されていることが予想され，そこで図 14 (a)，(b)，(c)に示すようにウイスカーのクリープ試験前 及び試験後の状態を TEMによって観察したところ，クリ 一プ試験後にはウイスカ一内部に新たな積層欠陥や転位(図 14(b)，(c)）の発生がみられた．Nutt ${ }^{14)}$ は SiC ウイスカー 中に内在する欠陥について検討を行い積層欠陥や部分転位 

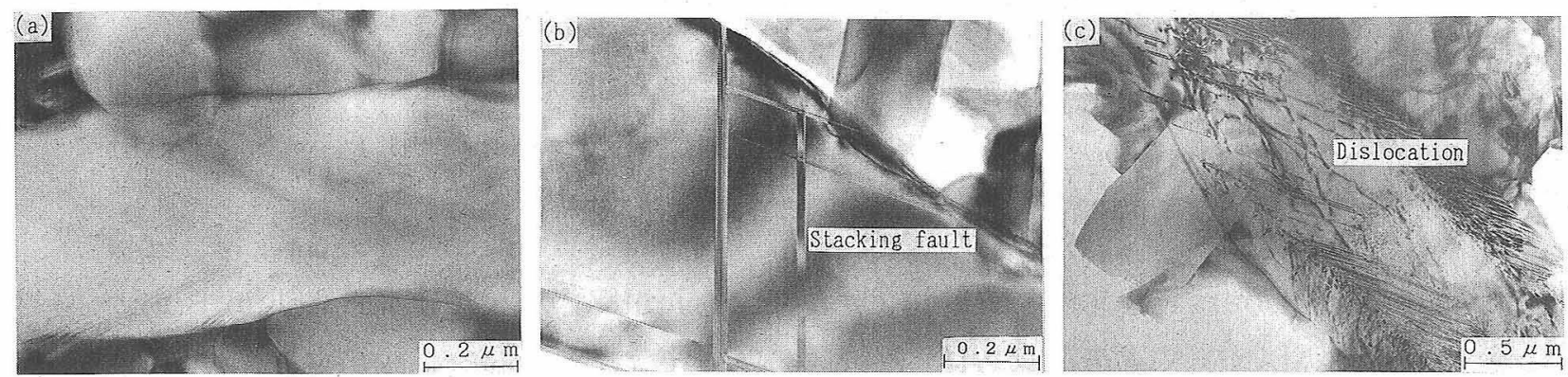

Fig. 14. TEM photographs of whiskers in composite (specimen A) before (a) and after (b, c) creep testing, showing the appearance of (b) stacking fault and (c) dislocation in the whisker.

更に空孔が存在することを報告している。このような初期 欠陷は外部応力により新たな積層欠陥を誘起したり転位の 移動を促進させる核となると考えられる。したがって，図 14(b)，(c)のような欠陷の発生はクリープ中にウイスカ一 が応力を負担していることを間接的に示唆するものであ る。

\section{4. 結 言}

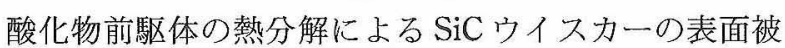
覆効果とドクターブレードによるウイスカーの配向効果に ついて検討し，以下の結果を得た。

表面被覆効果については，

(1) $\mathrm{Al}_{2} \mathrm{O}_{3}$ をウイスカー表面に被覆することにより複 合材の室温強度及び破壊鞋性が向上し， $K_{\mathrm{IC}}$ が $10.2 \mathrm{MPa}$. $\mathrm{m}^{1 / 2}$ ，強度が $1107 \mathrm{MPa}$ の高靶性・高強度複合材が得られ た.

（2）C被覆材ではディフレクションが多く見られたの に対し $\mathrm{Al}_{2} \mathrm{O}_{3}$ 被覆材ではブリッジングが多くみられ，界面 の結合状態の違いが示唆された。

(3) $\mathrm{Al}_{2} \mathrm{O}_{3}$ の被覆効果によりウイスカー表面がなめら かになり，マトリックスとの間に介在層が生成し，残留応 力値が低下することが明らかとなった。

(4) これらの結果加ら， $\mathrm{Al}_{2} \mathrm{O}_{3}$ 被覆により焼結後もウ イスカーの強度が保持され，更にウイスカー/マトリック ス間の界面結合力が変化しブリッジング機構が支配的にな ることにより蜮性が向上したものと推察された。

ウイスカーの配向による複合効果については,

(1) クラック進展面に対してウイスカーを垂直に配向 させて複合することにより，1250Cでの強度が $1180 \mathrm{MPa}$ とモノリシック材の約 2 倍の強度值を示す高温高強度複 合材が得られた。

（2）また高温クリープ時の歪み破断抵抗が増加し破断 時間孞モノリシック材の約 9 倍と大幅に向上し，垂直配 向によりクリープ特性を著しく改善できることが分かっ
た。

（3）このような高温での配向効果は，ウイスカーの架 橋による母材の変形抵抗の増大とウイスカー自身の応力負 担によるものと示唆された.

付 記 本研究は，通産省工業技術院の次世代産業基盤技術 研究開発制度に基づき，ファインセラミックス技術研究組合が新 エネルギー・産業技術総合開発機構（NEDO）加ら委託を受けた 「石炭ガス化用セラミックスタービンの要素技術開発」の一環と して行われたものである。

(1990年 5 月日本セラミックス協会 1990 年年会発表)

(1990年 9 月第 3 回日本セラミックス協会秋期シンポジムム発 表)

\section{文 献}

1) K. T. Faber and A. G. Evans, Acta Matall., 31, 565-76 (1989).

2) A. Kelly, Roy. Soc. Lond. A, 319, 95-116 (1970).

3) P. F. Becher, C. H. Hsueh, P. Angelini and T. N. Tiegs, J. Am. Cerm. Soc., 71, 1050-61 (1988).

4）新原晧一, セラミックス, 21, 581-89 (1986).

5）五戸康広，米澤武之，柘植章彦，小林通泰，日本セラミッ クス協会第 2 回秋期シンポシウム講演予稿集 (1989) pp. 500-01.

6）井上茂夫，内山哲夫，新原哠一，セラミックス，21，62129 (1986).

7）菅沼克昭，新原晧一，セラミックス，24, 937-44 (1989).

8) J. W. Laughner and R. T. Bhatt, J. Am. Ceram. Soc., 72, 2017-19 (1989).

9) N. D. Corbin, C. A. Willkens, J. L. Hammarstrom, V. K. Pujari, G. A. Rossi, K. N. Siebein, C. L. Chang and J. S. Hansen, Proc. 26 th Automot. Technol. Dev. Contract. Coord. Meet. 1988 (1989) pp. 235-41.

10) S. Kobayashi, T. Kandori and S/ Wada, Yogyo-Kyokai-Shi, 94, 903-05 (1986).

11) C. A. Willkens, N. D. Corbin, V. K. Pujari, R. L. Yeckley and M. J. Mangaudis, Ceram. Eng. Sci. Proc., 9, 1367-70 (1988).

12) F. Xia and Y. Z. Chin, J. Mater. Sci. Technol., 4, 201-04 (1988).

13）芦塚正博，渡辺雅彦，池山信秀，セラミックス論文誌， 98, 408-11 (1990).

14) S. R. Nutt, J. Am. Ceram. Soc., 67, 428-31 (1984). 